\title{
Hypogonadism and aging
}

\author{
F Lanzafame \\ From de Senectute: Age and Health Forum \\ Catanzaro, Italy. 5-7 December 2009
}

The Massachusetts Male Aging Study [1] shows that male hormones decrease with aging. This is due to some testicular and hypothalamic-pituitary defects. Impaired hypothalamic secretory reserve, resulting in a reduced and chaotic secretion of GnRH, reduced pituitary response to $\mathrm{GnRH}$, resulting in an increased but irregular LH pulse frequency [2]

With aging, there is a $1.3 \%$ increase of sex hormone binding globulin (SHBG) levels per year [3]. SHBG binds strongly to testosterone, resulting in a reduction of bioavailable testosterone. The age-related reduction of testosterone seems genetically determined ${ }^{3}$.The Testosterone reduction plays many effects on body composition [4]. Testosterone also operates its effects on the penis leading to a reduction of smooth muscle cells/connettive tissue rate, neuronal nitric oxide synthases, arterial influx/venoocclusion rate. Recently, three scientific societies published some recommendations for the investigation, treatment and monitoring of this kind of hypogonadism, that has been renamed Late Onset Hypogonadism [5]. These recommendationshave been updated lately [6] and shared by two more scientific societies.

Published: 19 May 2010

\section{References}

1. Feldman HA, Longcope C, Derby CA, Johannes CB, Araujo AB, Coviello AD, Bremner WJ, McKinlay JB: Age trends in the level of serum testosterone and other hormones in middle-aged men: longitudinal results from the Massachusetts male aging study. J Clin Endocrinol Metab 2002, 87(2):589-98.

2. Veldhuis JD, Zwart A, Mulligan T, Iranmanesh A: Muting of androgen negative feedback unveils impoverished gonadotropin-releasing hormone/luteinizing hormone secretory reactivity in healthy older men. J Clin Endocrinol Metab 2001, 86(2):529-35.

3. Krithivas K, Yurgalevitch SM, Mohr BA, Wilcox CJ, Batter SJ, Brown M, Longcope C, McKinlay JB, Kantoff PW: Evidence that the CAG repeat in the androgen receptor gene is associated with the age-related decline in serum androgen levels in men. J Endocrinol 1999, 162(1):137-42.

$\overline{\text { Territorial Centre of Andrology , Azienda Sanitaria Provinciale 8, Siracusa Italy }}$
4. Grant GF, Parr T: Decline of life's energy theory of ageing 2. Restoration of anabolic and requlatory processes Exp Opinion Ther Patents 2000, 10(12):1885-98.

5. Nieschlag E, Swerdloff R, Behre HM, Gooren LJ, Kaufman JM, Legros JJ, Lunenfeld B, Morley JE, Schulman C, Wang C, Weidner W, Wu FC: Investigation, treatment and monitoring of late-onset hypogonadism in males: ISA, ISSAM, and EAU recommendations. Int I Androl. 2005, 28(3):125-7.

6. Wang C, Nieschlag E, Swerdloff R, Behre HM, Hellstrom WJ, Gooren $L$, Kaufman JM, Legros JJ, Lunenfeld B, Morales A, Morley JE, Schulman C, Thompson IM, Weidner W, Wu FC: ISA, ISSAM, EAU, EAA and ASA recommendations: investigation, treatment and monitoring of late-onset hypogonadism in males. Int J Impot Res. 2009, 21(1):1-8.

doi:10.1186/1471-2318-10-S1-L23

Cite this article as: Lanzafame: Hypogonadism and aging. BMC Geriatrics 2010 10(Suppl 1):L23.
Submit your next manuscript to BioMed Central and take full advantage of:

- Convenient online submission

- Thorough peer review

- No space constraints or color figure charges

- Immediate publication on acceptance

- Inclusion in PubMed, CAS, Scopus and Google Scholar

- Research which is freely available for redistribution

Submit your manuscript at www.biomedcentral.com/submit
C Biomed Central 